\title{
Particulate emissions from large North American wildfires estimated using a new top-down method
}

\author{
Tadas Nikonovas, Peter R. J. North, and Stefan H. Doerr \\ Geography Department, College of Science, Swansea University, Singleton Park, Swansea, SA2 8PP, UK \\ Correspondence to: Tadas Nikonovas (tadas.nik@gmail.com)
}

Received: 31 March 2016 - Discussion started: 3 August 2016

Revised: 3 February 2017 - Accepted: 14 April 2017 - Published: 30 May 2017

\begin{abstract}
Particulate matter emissions from wildfires affect climate, weather and air quality. However, existing global and regional aerosol emission estimates differ by a factor of up to 4 between different methods. Using a novel approach, we estimate daily total particulate matter (TPM) emissions from large wildfires in North American boreal and temperate regions. Moderate Resolution Imaging Spectroradiometer (MODIS) fire location and aerosol optical thickness (AOT) data sets are coupled with HYSPLIT (Hybrid Single-Particle Lagrangian Integrated Trajectory) atmospheric dispersion simulations, attributing identified smoke plumes to sources. Unlike previous approaches, the method (i) combines information from both satellite and AERONET (AErosol RObotic NETwork) observations to take into account aerosol water uptake and plume specific mass extinction efficiency when converting smoke AOT to TPM, and (ii) does not depend on instantaneous emission rates observed during individual satellite overpasses, which do not sample night-time emissions. The method also allows multiple independent estimates for the same emission period from imagery taken on consecutive days.

Repeated fire-emitted AOT estimates for the same emission period over 2 to 3 days of plume evolution show increases in plume optical thickness by approximately $10 \%$ for boreal events and by $40 \%$ for temperate emissions. Inferred median water volume fractions for aged boreal and temperate smoke observations are 0.15 and 0.47 respectively, indicating that the increased AOT is partly explained by aerosol water uptake. TPM emission estimates for boreal events, which predominantly burn during daytime, agree closely with bottom-up Global Fire Emission Database (GFEDv4) and Global Fire Assimilation System (GFASv1.0) inventories, but are lower by approximately $30 \%$ compared to Quick
\end{abstract}

Fire Emission Dataset (QFEDv2) $\mathrm{PM}_{2.5}$, and are higher by approximately a factor of 2 compared to Fire Energetics and Emissions Research (FEERv1) TPM estimates. The discrepancies are larger for temperate fires, which are characterized by lower median fire radiative power values and more significant night-time combustion. The TPM estimates for this study for the biome are lower than QFED PM 2.5 by $35 \%$, and are larger by factors of 2.4, 3.2 and 4 compared with FEER, GFED and GFAS inventories respectively. A large underestimation of TPM emission by bottom-up GFED and GFAS indicates low biases in emission factors or consumed biomass estimates for temperate fires.

\section{Introduction}

Large and often severe fires in boreal and temperate forest regions alter atmospheric composition, considerably affecting the Earth's radiative budget (Langmann et al., 2009; Bond et al., 2013) and degrading air quality (Johnston et al., 2012). The burning regime in these regions is dominated by episodic extreme events (Stocks et al., 2002) emitting continental-scale plumes (Colarco et al., 2004) with interhemispheric transport potential (Damoah et al., 2004; Dahlkötter et al., 2013). Future climate predictions indicate both drier conditions and greater than average warming for northern latitudes, projecting a likely increase in area burned (Liu et al., 2010) and soil carbon consumption (Turetsky et al., 2015). For the quantification of smoke radiative forcing and impacts on human health, a realistic representation of biomass burning emissions in climate and air quality models is needed. Disagreement between bottom-up and top-down 
emission estimates of particulate matter, however, remains large (Kaiser et al., 2012; Ichoku and Ellison, 2014).

Bottom-up emission inventories use emission factors (EF) (Andreae and Merlet, 2001; Janhäll et al., 2010; Akagi et al., 2011; Urbanski, 2014), ratios of gases and particulate matter emitted per unit of dry fuel burned, compiled for different biomes from a range of burning experiment measurements across the globe. Emission factors are applied to biomass burned estimates, which are typically based on satellite observations of ubiquitous but highly variable fire activity. The Global Fire Emission Database (GFED) (van der Werf et al., 2010) makes use of satellite burned area products (Randerson et al., 2012; Giglio et al., 2013) and active fire pixel counts, while the Global Fire Assimilation System (GFAS) (Kaiser et al., 2012) employs fire radiative power (FRP) measurements (Giglio et al., 2006). Burned area estimates are converted to biomass burned using modelled carbon pools and soil-moisture-dependent combustion completeness characteristic to the fuel types. FRP-based methods rely on observed relationships between observed FRP and biomass combustion rates (Kaufman and Tanre, 1998; Wooster et al., 2003, 2005).

The more top-down methods utilize satellite aerosol optical thickness (AOT) observations. The Quick Fire Emission Database (QFED) uses regional AOT measurements to scale emissions based on EFs (Darmenov and da Silva, 2015). Similarly, atmospheric model assimilation of GFAS emissions (Kaiser et al., 2012) suggested a 3.4 global enhancement factor was needed to reconcile total particulate matter (TPM) estimates with observed AOTs. Purely topdown methods estimate emissions through inverse modelling of satellite AOT retrievals (Ichoku and Kaufman, 2005; Dubovik et al., 2008). A top-down global gridded Fire Energetics and Emissions Research (FEERv1) (Ichoku and Ellison, 2014) product is based on collocated satellite FRP and AOT observations. Inferred total particulate matter emissions rates are linked to observed FRP. The estimated TPM emission coefficients allow direct conversion from timeintegrated FRP to emitted particulate matter without invoking the emissions factors.

Global and regional particulate matter estimates from the bottom-up burned area and fire pixel-count-based GFED agree well with the FRP-based GFAS estimates. Model assimilations of these bottom-up emissions, however, suggest TPM underestimation by a factor of 2 to 4 compared to satellite AOT observations (Kaiser et al., 2012). Enhanced GFAS TPM estimates and scaled QFED agree better with top-down FEER emission coefficients on global scales. Notable discrepancies, however, are present for individual regions. North American emissions are larger for enhanced GFAS TPM and QFED when compared to top-down FEER, while FEER agrees closely with the bottom-up GFED inventory.

A number of uncertainties in both bottom-up and topdown estimates can contribute towards the apparent TPM discrepancies. Average EFs for different biomes conceal small sample numbers for some areas, and large variability in individual measurement results from within-biome inconsistencies in vegetation density, climatic and burning conditions (Van Leeuwen and van der Werf, 2011; van Leeuwen et al., 2014). Consumed biomass estimates inherit errors of satellite burned area (Randerson et al., 2012), fire location (Hyer et al., 2009) or FRP retrieval (Giglio et al., 2006), and depend on a range of assumptions on availability and consumption of carbon in aboveground and soil pools (French et al., 2004). Top-down approaches are affected by AOT retrieval error and large uncertainties in assumed smoke particle properties, which are required to relate aerosol extinction to particulate mass (Reid et al., 2005b). Moreover, estimates of emission rates based on near-source retrievals are representative of burning conditions at the time of satellite overpass. A recent study indicated that night-time TPM emissions might be underestimated by a factor of 20-30 for a large temperate forest fire in the western USA (Saide et al., 2015), stressing the need for better representation of night-time emissions in the inventories. Methods based on regional AOT observations, on the other hand, must take into account poorly constrained ageing effects (Reid and Hobbs, 1998; O’Neill et al., 2002).

This study presents estimates of particulate matter emissions from large wildfires with identifiable plumes in North American boreal and temperate regions. A newly developed top-down method is applied which attributes satellite aerosol observations to a specific fire event and emission period. Quantified daily fire-emitted AOT takes into account aerosols injected throughout the diurnal cycle and does not rely on instantaneous emission rates observed during a satellite overpass. In some cases, AOT attribution for the same emission period is achieved from satellite images taken on successive days, allowing for an assessment of uncertainty and an investigation of systematic changes in plume optical thickness over time. Total particulate matter is quantified by applying mass extinction efficiency, which is simulated using AERONET particle properties, and accounts for inferred water uptake by aerosols. The results are compared with existing estimates in order to investigate systematic differences between the approaches.

\section{Data and methods}

Daily total particulate matter emissions for large and persistent fire events were estimated by combining Moderate Resolution Imaging Spectroradiometer (MODIS) active fire observations and aerosol optical thickness retrievals with plume dispersion simulated using the Hybrid Single-Particle Lagrangian Integrated Trajectory (HYSPLIT) model. 

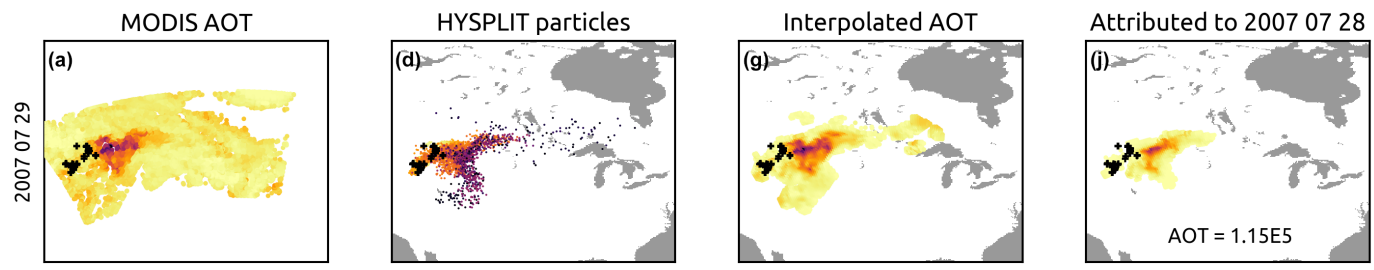

HYSPLIT particle age hours $\begin{array}{lllllllll}0 & 10 & 20 & 30 & 40 & 50 & 60 & 70\end{array}$
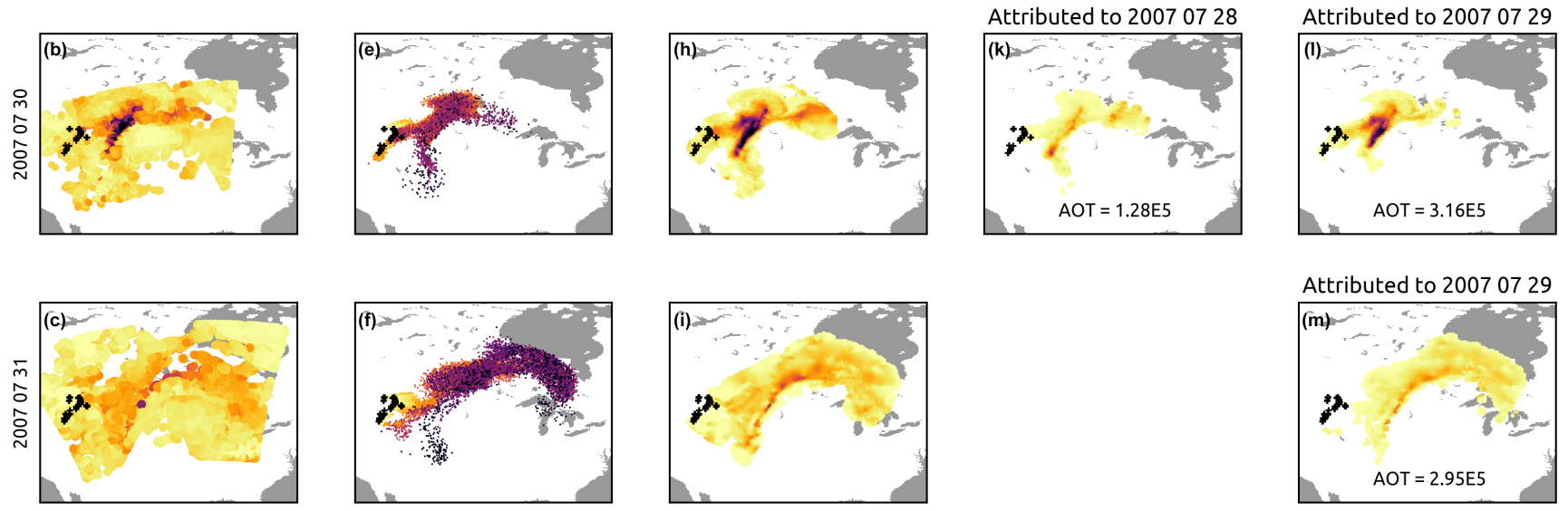

Figure 1. An illustration of the method showing an example of fire-emitted AOT attribution for two diurnal cycles of a temperate fire. Rows in the figure represent 3 successive days of satellite imagery from which the attribution was achieved. Columns from left to right show MODIS AOT retrievals for the day from a single platform with the highest coverage (a-c), snapshots of HYSPLIT particle positions and age taken at local noon (d-f), and AOT interpolated to $25 \mathrm{~km}$ equal-area grid (g-i). The two right columns show fire-emitted AOT attributed to 28 (j) and (k) and 29 (l) and (m) July 2007 determined from images taken on different days. Total attributed AOT is shown within the plots.

\subsection{Active fires}

To represent fire activity we used the active fire location data set MCD14ML produced by the University of Maryland and provided by NASA Fire Information for Resource Management System (Giglio et al., 2006). The data product is based on MODIS mid-range and thermal infrared observations. MODIS sensors are flown on board the sun-synchronous polar-orbiting Terra and Aqua satellites which respectively pass the equator at 10:30 and 13.30 local time during the daytime hours and at 22:30 and 01:30 at night. The instruments have a wide swath of approximately $2330 \mathrm{~km}$, each providing near-global coverage daily. For high latitudes the coverage is better due to increasing overlap between consecutive overpasses. Each detection in the data set represents an active fire in a $1 \mathrm{~km}^{2}$ pixel at the time of satellite overpass, and contains information on the retrieved fire radiative power.

\subsection{Fire event selection}

Large and long-lived fire events, likely strong emission sources, were identified and selected for the analysis. Burning episodes larger than $100 \mathrm{~km}^{2}$ are not numerous, but account for more than $80 \%$ of total burned area in boreal North America (Stocks et al., 2002; Kasischke et al., 2002), and are a dominant mode of burning in parts of temperate regions as well (Strauss et al., 1989). In order to identify such events, individual MODIS active fire detections were agglomerated into large wildfire events by performing twostep spatial-temporal clustering. First, any MODIS fire detections located closer than $10 \mathrm{~km}$ in space and $24 \mathrm{~h}$ in time were grouped together. Single detections not assigned to any of the formed clusters were removed from further analysis. The clusters were then filtered by selecting events with (i) a spatial bounding box containing all fire detections belonging to the cluster larger than $100 \mathrm{~km}^{2}$ and (ii) a duration longer than 7 days. The duration was determined by the time span between the first and the last MODIS active fire detections belonging to the cluster. The burning was considered uninterrupted if the largest temporal interval between subsequent MODIS fire observations was less than $24 \mathrm{~h}$. During the second step of clustering, any of the selected events active at the same time and located closer than $150 \mathrm{~km}$ were grouped into large burning episodes and assigned a unique source label. These events were classified into boreal and temperate fires using the dominant emission source given in the GFEDv4 inventory for areas and periods in which the events were active.

\subsection{Plume dispersion modelling}

Smoke transport for the selected fire events was simulated with the HYSPLIT model (Draxler and Rolph, 2003). Plume dispersion from a source location was represented by the motion of a large number of discrete particles moved by the 
wind field with mean and random components. Global Data Assimilation System (GDAS) meteorological archive data were employed to drive the model.

For each day of burning, particles were continuously released into the model domain from the locations of the individual active fire detections within the fire event. In order to represent fire diurnal cycle, different MODIS active fire observations were used to release particles for two $12 \mathrm{~h}$ intervals representing day and night emissions from 09:00 to 21:00 and from 21:00 to 09:00 local time respectively. Emission source number and locations for daytime periods were determined from the highest number of fire detections observed during a single Terra or Aqua daytime overpass with 10.30 and 13.30 equatorial crossing time. Similarly, emitted particle source numbers for the night periods were determined by the largest burning extent observed during one of the night-time overpasses with 22.30 and 1.30 equatorial crossing times. Notably, the Terra overpass at 22.30 at high latitudes makes observations of regions where local time is earlier than 21:00. In this study, however, all fires detected during this overpass were classed as night-time observations. If no valid observations were available for some of the time intervals, the count and fire pixel locations were set to a minimum non-zero value estimated for the burning episode from all daytime or night-time observations. This was done to avoid total temporary shut-down of the emissions, which is an unlikely scenario for a long burning episode. Every hour, 20 particles were released for each fire pixel. As a result, emitted particle number for a burning episode was determined by the number of active fire pixels observed during a given time period.

Particles were uniformly distributed between the surface and the top altitude of the planetary boundary layer as given in GDAS archive. Satellite-based plume height estimates (Val Martin et al., 2010; Peterson et al., 2014) indicate that in up to $80 \%$ of the events analysed, injection heights were limited to the planetary boundary layer. While confinement of the emissions to the mixing layer underestimates injection height for the most energetic burning episodes, such configuration should nonetheless represent the majority of burning episodes.

Throughout the simulations, modelled particle positions, their age and source burning event identifier were recorded each day at local solar noon. The generated point clouds were later used to compare against Terra and Aqua aerosol optical thickness (AOT) observations.

\subsection{Satellite aerosol data}

MODIS AOT collection 5.1 data products M*D04_L2 were used in this study. The dark target algorithm (Kaufman and Tanre, 1998; Levy et al., 2009) retrieves AOT at $550 \mathrm{~nm}$ and $10 \mathrm{~km} \times 10 \mathrm{~km}$ spatial resolution at nadir. MODIS pixel size increases with view angle, and pixels at the edge of the swath are approximately 9 times larger. For this study,
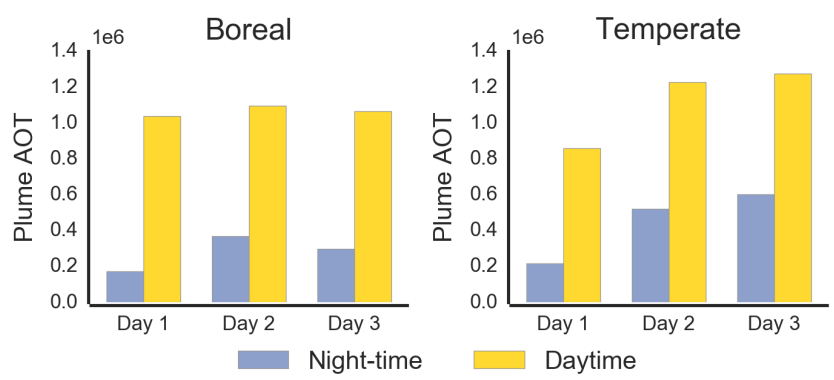

Figure 2. Changes in attributed AOT over time. Image shows 39 boreal and 37 temperate diurnal emission cycles for which estimates were obtained on 3 consecutive days, for both daytime and nighttime periods.

all M*D04_L2 AOT retrievals with quality assurance confidence $>0$ were selected. To maximize coverage, no cloud fraction filtering was applied. The AOT product global validation against ground-based AERONET AOT observations suggest a $1 \sigma$ error which increases linearly with aerosol loading $\pm(0.05+0.20 \%)$ (Levy et al., 2010) for overland cases. A regional MODIS M*D04_L2 AOT product validation (Hyer et al., 2011) indicates that performance varies greatly within North America. The study found that for $0.2<$ AOT $<1.4$ conditions, root mean square error varies from $-0.01+0.51 \times$ AOT in arid western America where retrieval is hindered by bright surfaces, to $0.01+0.31 \times$ AOT in boreal forest and $0.3+0.12 \times$ AOT in the eastern USA. The study reported positive bias in MODIS AOT for some locations, in particular for retrievals at extremely high aerosol loadings. The AOT retrieval values have an upper limit of 5.0, and in addition, opaque smoke is often rejected as bright surface or cloud by the algorithm (Livingston et al., 2014), preventing retrievals over extremely optically dense plumes. Consequently, AOT near the emission source is often not retrieved and the algorithm performs better when plumes are dispersed into regional haze.

\subsection{AOT attribution}

Elevated MODIS AOT observations were attributed to a specific fire event and emission period by comparing above background MODIS AOT retrievals to plume extent modelled by HYSPLIT (Fig. 2). Attribution required three pieces of information: (i) the event-specific background AOT value, (ii) the modelled plume extent at local solar noon for each day of burning and (iii) the coinciding MODIS AOT observations. First of all, the background AOT value was estimated for each of the selected burning events. It was determined by the median value of the AOT retrievals within $150 \mathrm{~km}$ radius from the fire event centroid observed 2 days prior to ignition. For each day of fire activity, a modelled plume extent (Fig. 2d-f) was determined from the locations of all HYSPLIT particle endpoints at solar noon, and AOT observations (Fig. 2a-c) with the highest spacial coverage for the day and 
plume area were selected from either the Terra or Aqua platform.

After the required information was obtained, the following steps were performed for each day of burning in an attempt to estimate fire-emitted AOT. First, plume regions bounding the particles released during the previous three daytime and night-time emission periods were identified. An estimation of the emission was attempted individually for each of the regions which represented plume areas that emitted during a specific time interval. This allowed the estimation of emitted AOT for up to 3 previous days from a single day of MODIS imagery. Importantly, such an approach allows the estimation of some emission periods even if a full MODIS plume overview is not available. Emitted AOT attribution was performed for the plume regions and satisfied two conditions: (i) the region had at least $80 \%$ of MODIS AOT areal coverage, assuming that a single AOT pixel represents $100 \mathrm{~km}^{2}$ area, and (ii) within-region AOT median value was higher than the estimated background value for the fire event.

MODIS AOTs for the selected plume regions were interpolated to a $25 \mathrm{~km}$-resolution equal-area grid (Fig. $2 \mathrm{~g}-\mathrm{i}$ ) by employing radial basis function interpolation with a linear kernel. Fire-emitted AOTs were estimated by subtracting the background value from the within-plume AOT. The estimated fire-emitted AOT in every within-plume grid cell was apportioned to different emission periods and different sources based on information on release time and source of the HYSPLIT particles contained within the cell. If all particles found within a grid cell were released during the same emission period and originated from a single source, the cell's AOT was simply attributed to that emission period and source. If a mixture of particles were found within a cell, indicating that multiple fires and multiple emission periods contributed towards the grid cell AOT, the attribution was performed by apportioning a grid cell's fire-emitted AOT in proportion to the numbers of modelled particles released during the emission periods and with origin found within the grid cell. For example, if a grid cell had an AOT value of 1, and 100 HYSPLIT particles were located within the cell during the satellite overpass, 80 of which were emitted two diurnal cycles ago and 20 during the previous diurnal cycle, the grid cell AOT was split accordingly between the emission periods. Panels (k) and (l) in Fig. 2 illustrate the partitioning of total plume AOT into two different emission periods. Similarly, if there were any particles emitted from different fire events, grid cell AOT was divided both between different emission periods and different fire events.

\subsection{Smoke aerosol properties}

The AErosol RObotic NETwork (AERONET) (Holben et al., 1998) level 2 retrievals (Dubovik and King, 2000) of aerosol microphysical and optical properties were used to characterize particles in plumes under investigation. AERONET consists of ground-based globally distributed sun-sky scanning photometers with a narrow field of view. The instruments are continuously monitored and calibrated, and the retrieved properties have estimated accuracy ranges. The direct sunbeam extinction measurements provide spectral AOT at several wavelengths ranging from 0.34 to $1.02 \mu \mathrm{m}$ with uncertainties of 0.01-0.02 (Dubovik et al., 2000). Measured AOT and angular distribution of sky radiances are used to retrieve column-integrated aerosol volume size distribution at 22 size bins from 0.05 to $15 \mu \mathrm{m}$ and spectral refractive index at 0.44 , $0.67,0.87$ and $1.02 \mu \mathrm{m}$. Size retrieval is expected to be accurate within $25 \%$ for particles with radii between 0.1 and $7 \mu \mathrm{m}$ and within $25-100 \%$ for size bins outside this range. Scans at high aerosol loadings (AOT $0.44 \mu \mathrm{m} \geq 0.4$ ) allow the retrieval of refractive index with estimated uncertainties of 0.04 and $30 \%$ for real and imaginary parts respectively (Dubovik et al., 2000).

Available observations within areas identified by the dispersion analysis as biomass burning plumes were attributed to a specific emission event and land cover type. Only retrievals containing refractive index (AOT $0.44 \mu \mathrm{m} \geq 0.4$ ) were selected. In order to minimize the presence of dust and urban aerosol dominated retrievals, cases with volume concentration of fine mode (particle diameter $<1 \mu \mathrm{m}$ ) fraction less than 0.8 , sphericity parameter lower than 0.98 and absorption Ångström exponent lower than 1 were filtered out. To make the samples more representative of plumes for which particulate matter was estimated, we selected AERONET observations within plume areas dominated by particles that had aged over 1 to 3 days.

\subsection{Water content retrieval}

The available AERONET spectral refractive indices were used to infer smoke aerosol water uptake. We employed the Maxwell Garnett effective medium approximation (Bohren and Huffman, 1983) which provides a method to derive volume fractions of the components in the mixture if their refractive indices are known. The approach for retrieving black carbon concentrations from AERONET climatologies is described in detail and demonstrated by Schuster et al. (2005). It was further developed to infer brown carbon content (Arola et al., 2011), aerosol water uptake (Schuster et al., 2009), and to simultaneously retrieve fractions of carbonaceous absorbers and dust (Schuster et al., 2016).

To infer water content we employed a three-component mixture of black carbon and organic-inorganic matter included in a water host (Table 1). For black carbon we assumed the refractive index and density suggested in Bond and Bergstrom (2006). The second inclusion was used to represent a broad range of chemical species observed in biomass burning plumes (Brock et al., 2011), including organic carbon, ammonium sulfate and ammonium nitrate. These species were represented by a single component because they have $n$ values close to 1.53 . This value is characteristic of dry ammonium sulfate (Toon et al., 1976), was 
Table 1. Real $(n)$ and imaginary $(k)$ parts of refractive index, and density $(p)$ of the components used in the Maxwell Garnett effective medium approximation calculations. All components were assumed to have spectrally flat refractive index. Uncertainty in $p$ for the species represented by the second inclusion was propagated into combined errors of retrieved water volume fraction and particle density.

\begin{tabular}{|c|c|c|c|c|}
\hline Species & $n$ & $k$ & $\begin{array}{r}p \\
\left(\mathrm{~g} \mathrm{~cm}^{-3}\right)\end{array}$ & Source \\
\hline Black carbon & 1.95 & 0.79 & 1.8 & Bond and Bergstrom (2006) \\
\hline Organic and inorganic compounds & 1.53 & 0.00 & $1.2-1.4$ & $\begin{array}{l}\text { Kirchstetter et al. (2004); } \\
\text { Turpin and Lim (2001); } \\
\text { Toon et al. (1976) }\end{array}$ \\
\hline Water & 1.33 & 0.00 & 1.0 & \\
\hline
\end{tabular}

measured for organic carbon (Kirchstetter et al., 2004) and lies within the range of values measured for dry organic compounds (Dick et al., 2007). Volume fractions of the inclusions and water host were retrieved in two steps. First, we deduced the amount of black carbon utilizing the spectral imaginary refractive index of the component. The Maxwell Garnett mixing rule was applied to a range of different fractions of black carbon in a water with negligible imaginary index. Volume fraction of the inclusion was estimated, determining the configuration which provided minimum $\chi^{2}$ :

$\chi^{2}=\sum_{i=1}^{N} \frac{\left(k_{i}^{\mathrm{ret}}-k_{i}^{\mathrm{mg}}\right)^{2}}{\left(k_{i}^{\mathrm{ret}}\right)^{2}}$,

where $k_{i}^{\text {ret }}$ is the AERONET-retrieved imaginary index, $k_{i}^{\mathrm{mg}}$ is the value calculated by the Maxwell Garnett mixing rule, $i$ is the summation over the selected AERONET wavelengths. We used AERONET $k$ at 0.87 and $1.02 \mu \mathrm{m}$ to retrieve black carbon fraction, assuming that it is the only absorber in this part of the spectrum. $k$ at shorter wavelengths can be enhanced by absorption by organic carbon (Kirchstetter et al., 2004), which is retrieved as a part of the second inclusion. After volume fraction of black carbon was established, we kept it fixed and varied the fraction of the second inclusion in the mixture, minimizing the Eq. (1) for the real part of the refractive index at all four AERONET wavelengths.

\subsection{Conversion of aerosol optical thickness to mass}

Particle mass within the atmospheric column can be inferred from smoke AOT observations if mass extinction efficiency $\left(B_{\text {ext }}\right)$ is known:

$M_{\text {plume }}=\frac{\tau_{\text {plume }}}{B_{\text {ext }}}$,

where $M_{\text {plume }}$ is mass of plume aerosols, and $\tau_{\text {plume }}$ is a product of mean fire-emitted AOT and plume area. $B_{\text {ext }}$ represents extinction in area units per unit of aerosol mass, usually expressed as $\left[\mathrm{m}^{2} \mathrm{~g}^{-1}\right]$. It can be measured or calculated invoking Mie theory. In situ measurements of fresh North American smoke suggest $B_{\text {ext }}$ values ranging from
3.9 to $4.6 \mathrm{~m}^{2} \mathrm{~g}^{-1}$ (Hobbs et al., 1996). Equivalent measurements for aged plumes are not available for the region, but smoke samples collected in other forest ecosystems indicate slightly larger $B_{\text {ext }}$ values ranging from 4.0 to $5.3 \mathrm{~m}^{2} \mathrm{~g}^{-1}$ (Reid et al., 2005b; Chand et al., 2006) for older emissions. Similar $B_{\text {ext }}$ at $550 \mathrm{~nm}$ ranging from 4.5 to $5.2 \mathrm{~m}^{2} \mathrm{~g}^{-1}$ were inferred by Reid et al. (2005b) from AERONET retrievals (Dubovik et al., 2002) of dominant particle size distributions and index of refraction for North American boreal regions. Ichoku and Ellison (2014) applied a uniform $4.6 \mathrm{~m}^{2} \mathrm{~g}^{-1}$ value (Reid et al., 2005b) in deriving FEER TPM emission coefficients. Notably, plumes in their analysis were relatively young, up to a few hours old at most. In contrast, smoke discussed in this study is aged for a few days.

To avoid making assumptions about smoke optical properties, $B_{\text {ext }}$ was inferred utilizing available AERONETretrieved refractive indices and particle size distributions. We used Mie code (Bohren and Huffman, 1983) to calculate $B_{\text {ext }}$ assuming spherical internally mixed particles:

$B_{\text {ext }}=\frac{\int_{r_{\min }}^{r_{\max }} \sigma_{\text {ext }}(n, k, \lambda, r) \frac{\mathrm{d} N(r)}{\mathrm{d} \ln r} \mathrm{~d} \ln r}{V_{\text {dry }} \rho_{\mathrm{dry}} \frac{3}{4} \pi \int_{r_{\min }}^{r_{\max }} r^{3} \frac{\mathrm{d} N(r)}{\mathrm{d} \ln r} \mathrm{~d} \ln r}$,

where $\sigma_{\text {ext }}$ is the extinction cross section of a single particle which depends on refractive indices $(n, k)$, wavelength and particle radius $(r)$. $V_{\text {dry }}$ is particle dry volume fraction, $\rho_{\text {dry }}$ is particle dry fraction density, both determined from aerosol water uptake analysis (Sect. 2.7). $\sigma_{\text {ext }}$ was calculated at $0.55 \mu \mathrm{m}$ using Mie code for every radius in the AERONET size distribution and averaged $n$ and $k$ retrievals at 0.44 and $0.67 \mu \mathrm{m}$. The numerator in the Eq. (3) is the single particle extinction cross sections integrated over number distribution, while denominator is aerosol dry fraction mass within the column given by the product of particle density and integrated particle volume.

\subsection{Uncertainty in derived quantities}

Uncertainties in AERONET smoke aerosol properties, particle density and daily fire-emitted AOT attribution were prop- 

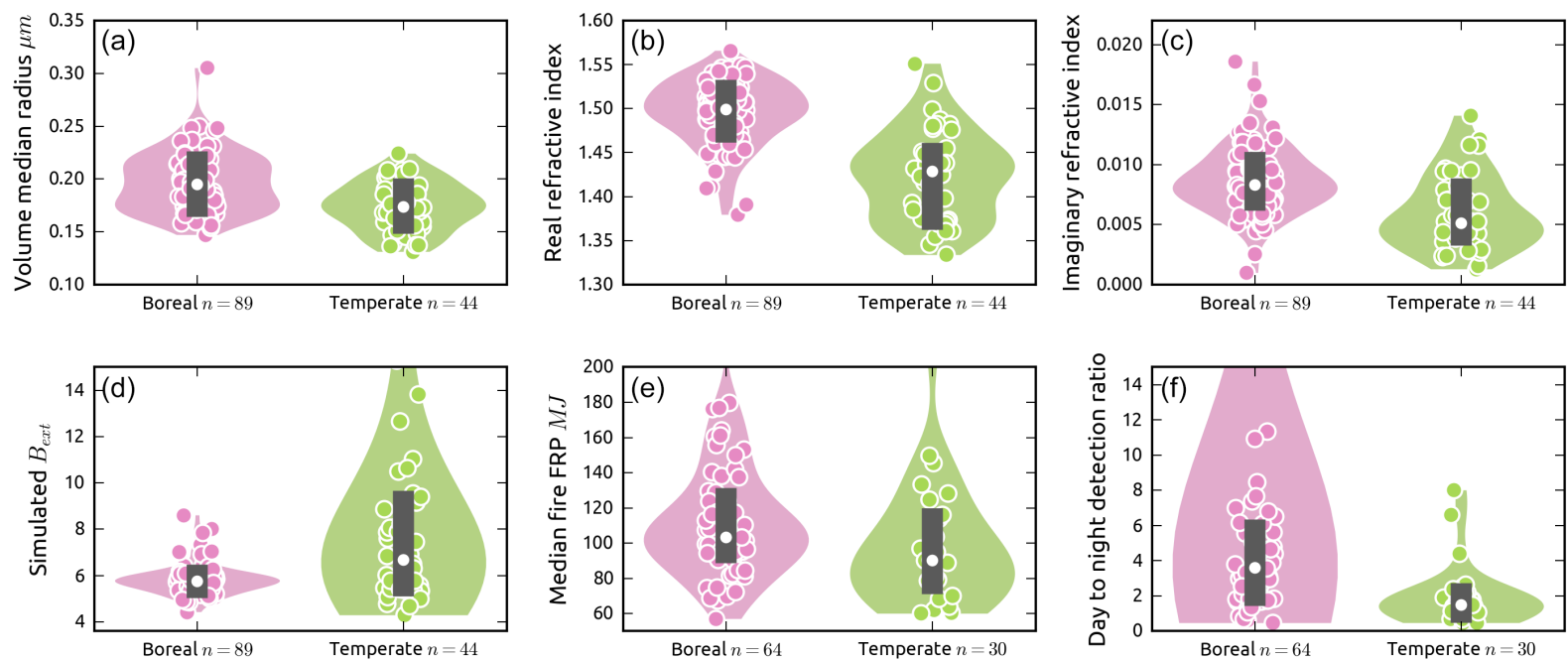

Figure 3. Distributions of AERONET-retrieved particle properties (a-c) attributed to boreal and temperate fires, simulated mass extinction efficiencies (d), median MODIS FRP values (e) and ratios of daytime to night-time active fire detection counts observed during a single overpass (f). Shown are kernel density estimates and individual observations; boxes indicate median values and interquartile range.

agated using a Monte Carlo method, retrieving water volume fraction, mass extinction efficiency and deriving total TPM estimates for the biomes. Throughout the study we report median values and interquartile range for the distributions, unless otherwise stated.

\section{Results and interpretation}

Attribution of fire-emitted AOT for at least two diurnal cycles of emission was achieved for 94 large fire events. Boreal sources constitute 64 of the events, with the remainder identified as temperate forest fires. In total, fire-emitted AOT estimates were obtained for 620 days of burning. The daily attributed AOTs include particulate matter emitted during the full diurnal cycle of emission accounting for both daytime and night-time emissions. These estimates are representative of large and likely intense burning events and clear sky conditions for which sufficient satellite observations were available. Particulate matter emitted by the events on the days for which our estimates were obtained account for approximately 3 to $20 \%$ of total GFED and GFAS emissions for the North America region depending on the year. The representativeness, however, is probably better than suggested by this figure, assuming that emissions from the sampled events were similar on the days for which estimation was not achieved.

\subsection{Systematic changes in plume attributed AOT}

An important advantage of the AOT attribution method presented in this study is that it allows us to gauge combined errors originating from uncertainties in plume injection height, dispersion modelling, MODIS AOT retrievals and applied in- terpolation. Critically, any systematic changes in fire-emitted smoke optical thickness in evolving plumes can be inferred as well. This was facilitated by a number of cases in which two or more AOT attributions based on imagery and taken on consecutive days were performed for the same emission period. Figure 2 shows daily AOT estimates for days of emission for which the attribution was achieved from imagery taken on three consecutive days, for both night-time and daytime emission periods.

Overall, determined smoke AOT based on retrievals at later stages of plume development tend to have a positive bias compared to estimates for the same period of emission obtained on previous days. Notably, the largest increase in estimated AOT is observed when comparing estimates for the previous night-time emission cycle (smoke aged for 3 to $15 \mathrm{~h}$ ) to AOT attributed to the same period determined from the following day's imagery, after the plume has aged for an additional $24 \mathrm{~h}$. Inferred changes in daytime fire-emitted AOT over the first 2 days of ageing are smaller. Optical thickness for temperate smoke increases by approximately $30 \%$ from the first observation of daytime emissions which are already aged for 15 to $27 \mathrm{~h}$, compared to estimates for the same emission period determined from the imagery collected the following day. Changes in estimated daytime fireemitted AOT for boreal plumes appear to be negligible. Notably, consecutive $24 \mathrm{~h}$ of ageing does not change estimated plume AOT significantly for both biomes and both daytime and night-time emissions. A slight decrease in optical thickness is observed for boreal smoke, but this should be treated with caution given the level of uncertainties involved. For the limited number of emission cycles presented in Fig. 2, contributions of day and night emissions appear to differ between the biomes. Night-time emissions constitute $30-40 \%$ of to- 
tal fire-emitted AOT for temperate events. Boreal plumes are dominated by daytime emissions with night-time emissions comprising under $20 \%$ of total daily AOT. The difference is influenced by a larger number of night-time active fire pixels observed for temperate fires (Fig. 3f) and, consequently, more particles released during the night-time emission period in the dispersion simulations.

The effect of increasing AOT over time could be in part explained by uncertainty in plume dispersion modelling. However, the modelling error is expected to increase with time and hence should be manifested by progressively larger disagreement and biases for older estimates. In contrast, the results suggest that the agreement between the estimates for the same emission period is reasonably static across the plume age categories (Fig. 4b). The bias, on the other hand, is clearly largest for the first and the second plume observations within the first two diurnal cycles. It is possible that the model-emitted night-time particles get mixed with subsequent daytime emissions during the transport, effectively scavenging part of AOT from the other emission periods during the attribution. However, the observed daytime AOT tends to increase as well. Additionally, there are significant differences in inferred AOT changes between boreal and temperate plumes, indicating that some physical processes might be driving the change.

Particulate matter estimation and comparison with other methods are based on fire-emitted AOT during emission cycles starting and ending at 00.00 UTC. For 159 and 125 emission periods for boreal and temperate events respectively, AOT was determined from imagery taken on consecutive days allowing us to estimate the attribution error. These estimates do not include the problematic previous night emissions. Figure 4a shows the differences in fire-emitted AOT estimates for these cases. Given that the differences are approximately normally distributed, we propagated $50 \%$ one sigma uncertainty in attributed daily fire-emitted AOT to derive confidence intervals for TPM emission estimates.

\subsection{Fire FRP and daytime-night-time pixel counts}

Large and persistent fire events discussed in this study exhibit distinctiveness in FRP values and diurnal burning cycle. Median MODIS FRP retrieved for the boreal fires is 103 (94-117) MW, while median FRP for temperate events is 90 (78-103) MW. This suggests higher burning intensity and combustion rates for boreal fires. A more striking difference, however, emerges when comparing ratios of maximum active fire pixel counts detected during individual daytime and night-time satellite overpasses. The proportion of active fires at night are typically much higher for temperate fires. The average daytime to night-time pixel count ratio is $1.4(1.1-1.9)$ for the fires in this biome compared to median value of 3.6 (1.8-4.8) for boreal fires. Such a pattern indicates a higher contribution of night burning for temperate events.

\subsection{Variability in particle properties}

The identified AERONET observations of boreal and temperate smoke suggest distinctiveness in retrieved size distributions and refractive index (Fig. 3a-c). The selected observations indicate that boreal emissions tend to have larger particles with median volume median radius value of $0.19(0.17-$ $0.21)$ compared to $0.17(0.16-0.19) \mu \mathrm{m}$ obtained for temperate smoke. These differences may be influenced by differences in combustion phase between the biomes. Very intense and predominantly flaming fires emit larger particles than events with more important smouldering combustion (Reid et al., 2005a). Substantial differences exist when comparing the indexes of refraction for boreal and temperate smoke. Boreal plumes exhibit higher median $n$ value of $1.49(1.47-1.52)$ in contrast to $1.43(1.37-1.45)$ observed for plumes attributed to temperate forest fires. Although boreal smoke generally is more absorbing with median $k$ value $0.008(0.007-0.01) i$ compared to the $0.005(0.004-0.008) i$ value obtained for temperate emissions, plumes from both biomes are only weakly absorbing and characteristic $k$ values have a negligible influence on calculated $B_{\text {ext }}$. Variability in the real part of the refractive index between the plume categories, on the other hand, is larger and indicates differences in particle chemistry.

\subsection{Inferred volume water fractions}

Maxwell Garnett medium approximation calculations using the discussed optical constants result in substantially different inferred water content for the two sources (Fig. 5). The variability is mainly driven by the real part of the refractive index. Inferred median black carbon fractions are less than $1 \%$ for both classes and thus have minimal impact on water content retrieval. Median water volume fraction for boreal fires is $0.15(0.1-0.31)$, whereas temperate plumes have median value of $0.47(0.29-0.67)$. The derived values agree with water volume fractions inferred by Schuster et al. (2009) using a similar approach, although dust was not included as one of the components in our retrieval. Converting the inferred median water volume fractions to geometric hygroscopic growth factors results in values of 1.05 and 1.24 for boreal and temperate plumes respectively. These estimates compare favourably to measured factors for biomass burning smoke (Swietlicki et al., 2008), indicating near-hydrophobic particles for boreal plumes, while temperate smoke could be classed as less hygroscopic. Notably, measured geometric hygroscopic growth factors are reported at $90 \%$ relative humidity. In contrast, water volume fractions inferred in this study are representative of ambient humidity levels, and as a result direct comparison is not very meaningful.

The main limitations of the presented method are (i) the assumption that aerosols with $n \geq 1.53$ are dry and (ii) large uncertainties in the chosen $n$ values and different components used in the retrieval. In addition to increasing water content, 

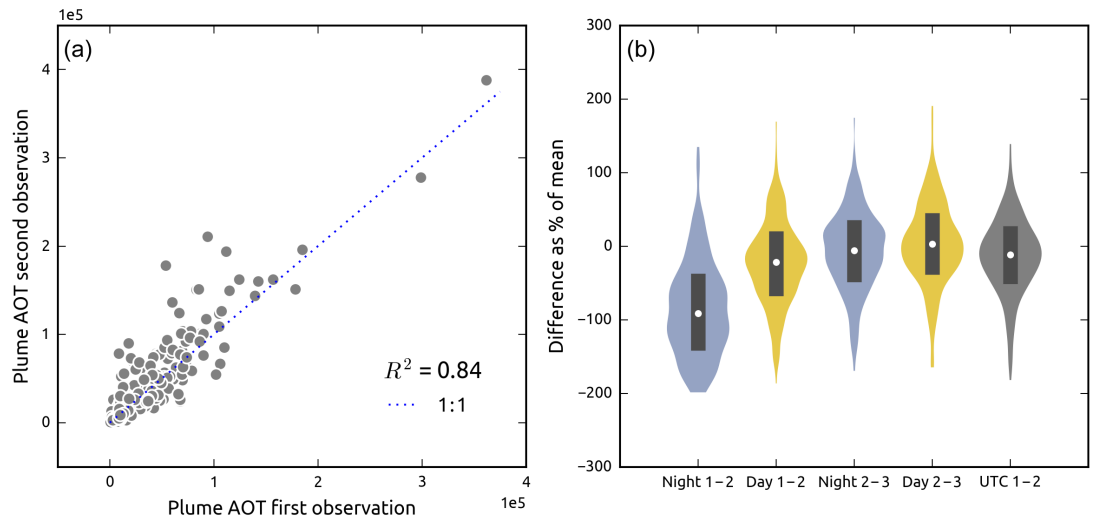

Figure 4. Fire-emitted AOT for 284 cases with two estimates for the same diurnal emission period starting and ending at 00:00 UTC, obtained at different stages of plume development (a). Plot (b) shows differences between two fire-emitted AOT estimates expressed as a percentage of their mean value for the three night-time and daytime emission periods and two UTC periods shown in (a).

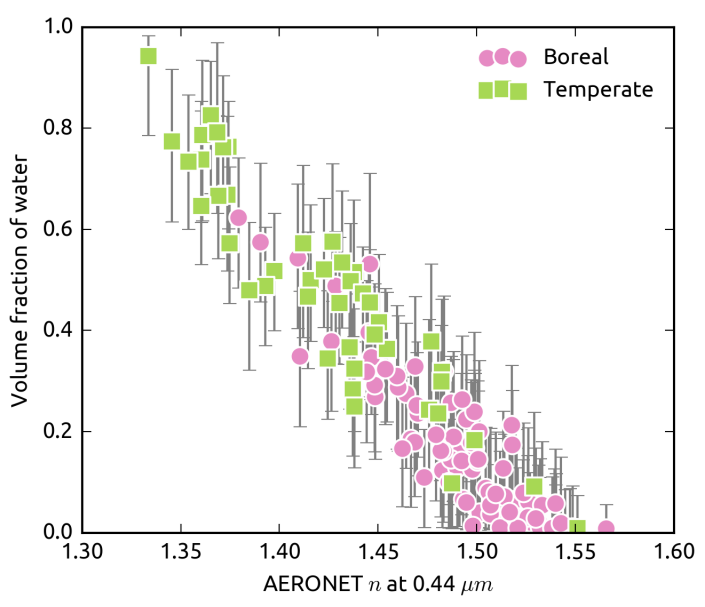

Figure 5. Inferred volume fraction of water. Error bars show interquartile range of inferred values resulting from uncertainties in AERONET particle properties.

formation of organic compounds may alter aerosol optical properties. Measured $n$ for dry ambient organic aerosol are typically lower than the 1.53 value used in this study, ranging from 1.47 to 1.53 (Dick et al., 2007) and appear to change with age (Rudich et al., 2007). Although the uncertainties in AERONET properties and particle density were propagated in the retrieval, water fractions inferred in this study critically depend on $n$ of the dry major component being close to 1.53. Any departures from this value result in inaccurate water uptake retrieval.

\subsection{Simulated mass extinction efficiencies}

The differences in plume particle properties, primarily $n$ and particle size, coupled with distinctiveness in inferred volume water fractions, drive differences in simulated $B_{\text {ext }}$ for the dry volume content of the plumes. Boreal plumes have larger particles, higher values of refractive index, but smaller water fractions and hence a lower median $B_{\text {ext }}$ value of 5.7 (5.16.5), while emissions originating from temperate forests have a median $B_{\text {ext }}$ value of $6.7(5.4-9.2) \mathrm{m}^{2} \mathrm{~g}^{-1}$ due to inferred greater water content. The identified AERONET observations are for ambient plumes which are aged for at least 1 to 3 days, and consequently, computed $B_{\text {ext }}$ values for dry volume fractions are larger than the $4.7 \pm 0.7 \mathrm{~m}^{2} \mathrm{~g}^{-1}$ value suggested for dry aged boreal and temperate emissions (Reid et al., 2005b). Somewhat higher values ranging from 4.7 to $5.5 \mathrm{~m}^{2} \mathrm{~g}^{-1}$ were calculated (Reid et al., 2005b) for a set of AERONET retrievals from North American boreal forest (Dubovik et al., 2002). The main difference between that aerosol climatology and the retrievals used in this study are in the real part of the refractive index. Dubovik et al. (2002) climatology for boreal smoke generally represents drier plumes with an average $n$ value of 1.5 compared to 1.49 and 1.43 median $n$ values attributed to boreal and temperate emission in this study.

\subsection{Interpretation of changes in smoke optical thickness}

The increase in attributed AOT in aged plumes determined in this study is consistent with well-documented smoke particle evolution. Aerosols grow considerably in size as plumes age. Particles undergo rapid changes during the first few hours after emission due to combined effects of condensation and coagulation (Reid and Hobbs, 1998), with reported growth rates in volume median radius as high as $0.04 \mu \mathrm{m}$ per hour (Hobbs et al., 1996). On a timescale of days, plume particles continue to grow in dense plumes but at substantially lower rates, primarily due to coagulation and hygroscopic growth. Reported increases in volume median radius at these timescales are of the order of 0.02-0.03 $\mu \mathrm{m}$ (Reid et al., 2005a; Nikonovas et al., 2015). Condensation of organic and inorganic species and secondary particle production increase particle plume 
mass, while coagulation only transforms particle distribution. Both processes alter smoke optical thickness, mainly by enlarging scattering cross section and scattering efficiency, which is a strong function of particle size. Condensation has been reported to increase particle mass by up to $30-40 \%$ in Amazonian plumes, but is thought to be important only during the first $24 \mathrm{~h}$ at most (Reid and Hobbs, 1998). The inferred increase in fire-emitted AOT over the first 2 days of ageing reported in this current study only partially overlaps with this period. The first few hours of plume development when condensation is thought to be the most active are not represented; therefore condensation is unlikely to contribute significantly towards the inferred AOT growth. A growth in volume median radius of $0.02 \mu \mathrm{m}$ due to coagulation theoretically could increase scattering efficiency by up to $30 \%$ without changes in plume mass, but this process cannot explain the differences in the magnitude of AOT change observed between the biomes.

An additional factor driving changes in AOT is water uptake by smoke particles. Absorption of water depends on air relative humidity and aerosol solubility which in turn tends to increase with atmospheric processing. It increases particle size further, enhancing scattering cross section. Hygroscopic growth factors measured and inferred by optical methods for biomass burning smoke at $80 \%$ relative humidity range from 1.1 to more than 2 (Kotchenmther and Hobbs, 1998; Kreidenweis et al., 2001; Magi and Hobbs, 2003). Reid et al. (2005b) suggested an average enhancement factor of $1.35 \pm 0.2$. $B_{\text {ext }}$ values derived for dry volume fraction in this study suggest median scattering cross-section enhancement factors of 1.2 and 2 for boreal and temperate plumes, assuming the $4.7 B_{\text {ext }}$ value for dry smoke (Reid et al., 2005b).

Notably, the magnitude of AOT increase over time, shown in Fig. 2, corresponds to inferred median water fractions for the two biomes. Temperate emissions exhibit generally hydrophilic particles with much greater water content, while boreal plumes seem to contain much less aerosol water. This distinctiveness could be due to different ratios of smouldering and flaming combustion. Field measurements indicate that prescribed burns, and in particular wildfires in temperate regions, have lower combustion efficiencies (Urbanski, 2014). Temperate fires discussed in this study have lower mean FRP values and a less pronounced diurnal burning cycle, and the emitted plumes have higher ratios of night-time emissions. Smouldering night-time smoke has been reported to contain more soluble organic compounds (Hoffer et al., 2006), which could explain the presence of more hydrophilic aerosols in temperate plumes. In addition, factors not accounted for in this study, such as significant differences in relative humidity and atmospheric processing between the biomes, may be partly responsible for the inferred variability in water uptake.

\subsection{Daily TPM estimates for individual fires}

On an individual event basis the relationships between daily particulate emissions given by the global inventories and this study exhibit varying degrees of agreement. Figure 6 shows the TPM from this study and GFED for the events for which estimation was performed for at least seven diurnal cycles. Although some fires exhibit only fair or weak agreement, the result is nonetheless encouraging considering the error in AOT attribution and conversion to TPM method in this study, and large uncertainty associated with the date of burn in daily burned area product (Giglio et al., 2013) on which GFED depends. Robust linear fits between GFED TPM and daily estimated TPM, shown in Fig. 6, indicate considerable variability in slopes, even in comparison to the events with generally good agreement. This suggests distinctive combustion and emission characteristics for individual events. As well as variability on a per burning event basis, large differences exist when comparing relationships for fires in boreal and temperate forests. Notably, for every tonne of GFED TPM, this study shows TPM ranges from 0.46 to over $2 \mathrm{t}$ for boreal burning events, while for temperate fires the conversion factors range from approximately 1 to more than 5 . The relationships are similar in terms of agreement when comparing daily TPM estimates with other inventories (not shown), but scaling factors, which are needed to reconcile the estimates, differ.

\subsection{Comparison of total emissions and emission coefficients}

Total TPM emission estimates obtained in this study for the wildfires examined are large in comparison to FEER and, to a lesser degree, to GFED and GFAS inventories, but are smaller than QFED estimates (Fig. 7). QFED emissions are reported for $\mathrm{PM}_{2.5}$ aerosol fraction only, which typically constitutes 70 to $85 \%$ of TPM for the biomes discussed (Akagi et al., 2011). As a result, QFED TPM estimates should be approximately 20-40\% higher than indicated in Fig. 7 .

Substantial differences exist between the estimates for boreal and temperate fires. For boreal forest events, total TPM emissions for this study are in close agreement with the bottom-up GFED and GFAS TPM estimates. The agreement indicates that application of the proposed 2.2 enhancement factor (Kaiser et al., 2012) to GFAS TPM would overestimate boreal emissions for the events discussed. In fact, assuming an increase in aerosol mass and AOT in ageing plumes, boreal TPM emissions for this study are low compared the near-source GFED and GFAS estimates. Regional AOT-based QFED inventory suggests $\mathrm{PM}_{2.5}$ emissions are higher by $40 \%$, while near-source FEER TPM estimates are smaller by a factor of 2.8 when compared to TPM for this study.

For temperate forests, a striking contrast exists between GFED and GFAS inventories and methods based on regional 

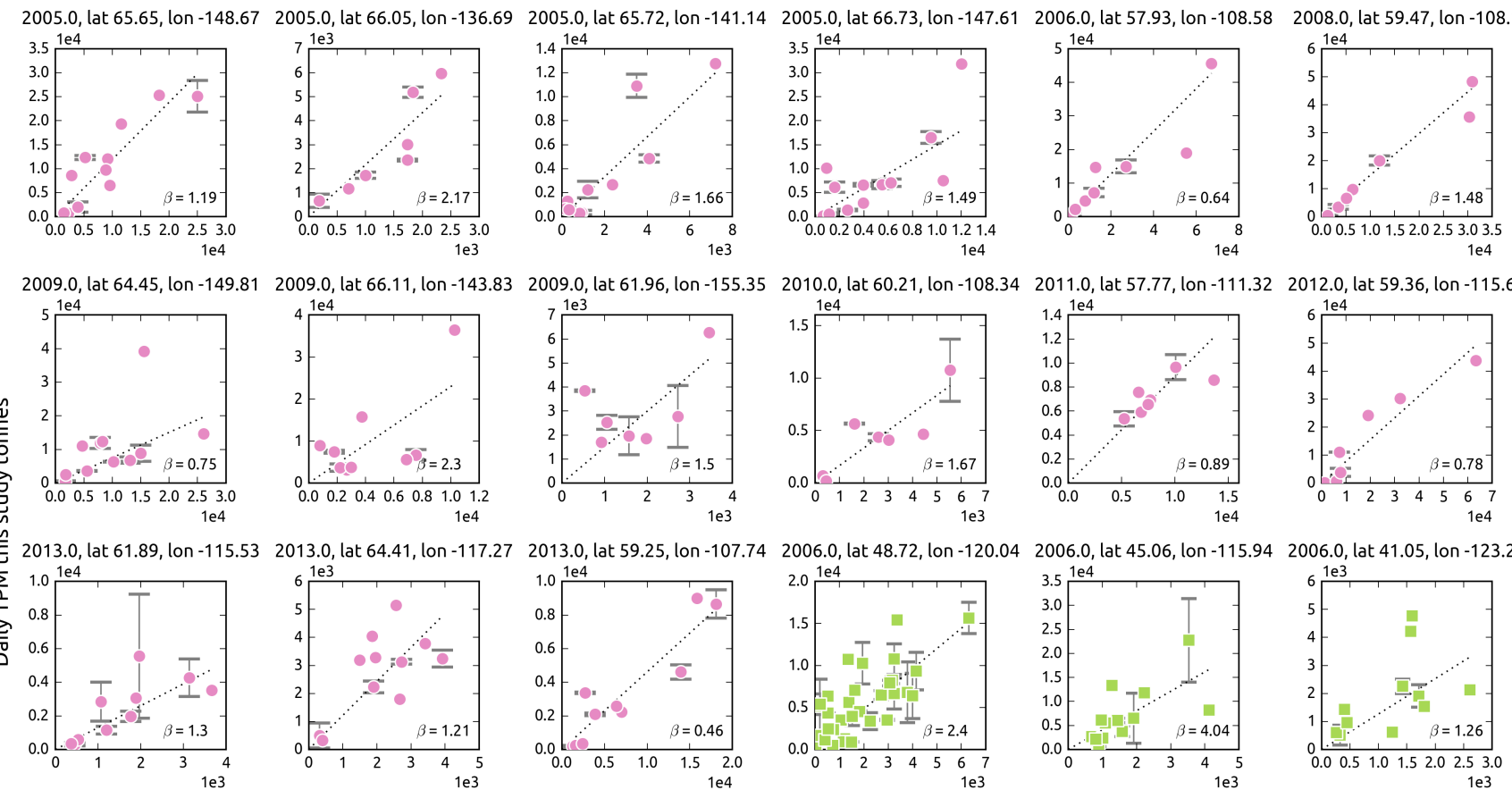

2012.0, lat 59.36, lon -115.62
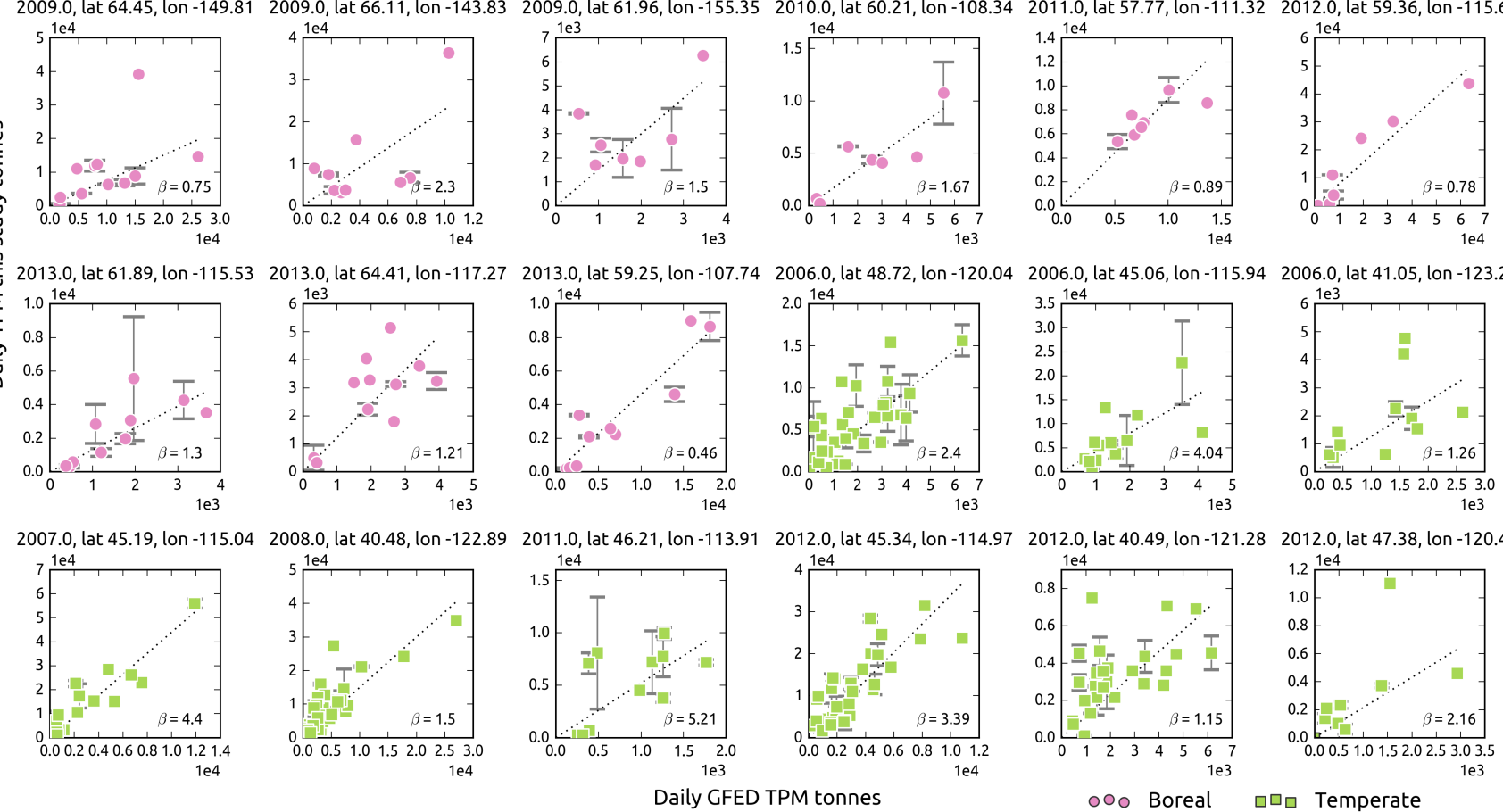

Figure 6. Daily estimated TPM from this study and GFED for individual fire events. Error bars represent difference between two TPM values for the days of emission for which two estimates were obtained. Robust linear fits are shown; $\beta$ parameter indicates the slope.

AOTs. The largest estimates are given by the QFED inventory, which suggests $\mathrm{PM}_{2.5}$ emissions are higher by $50 \%$ than the TPM estimates for this study. If bottom-up estimates of the boreal emissions agree well with this study's TPM for temperate events the discrepancies are much larger. Scaling factors of 3.2 and 4 are needed to reconcile GFED and GFAS emissions with the estimates obtained in this study. FEER emissions are closer to bottom-up approaches suggesting much lower emitted TPM compared to the other top-down methods. This appears to be characteristic to North America as has been reported in Ichoku and Ellison (2014), indicating potential underestimation of the emissions in the region. For other continents, FEER generally predict higher TPM emissions than the bottom-up inventories and agree closely or even exceed QFED PM 2.5 estimates.

The above emission budgets suggest particulate matter emission coefficients of 27 (23-30) and 31 (24-37) g per $\mathrm{MJ}^{-1}$ of time integrated GFASv1.0 FRP (Table 2). They comprise approximately $70 \%$ of coefficients derived for QFED PM 2.5 emissions, and are 2.5 times larger than equivalent values derived using FEER emission coefficients. No-
Table 2. Total particulate matter emission coefficients derived using GFASv1.0 FRP product and particulate matter emission estimates for the burning events discussed.

\begin{tabular}{|c|c|c|}
\hline & \multicolumn{2}{|c|}{$\begin{array}{l}\text { Emission coefficients } \\
\qquad\left(\mathrm{g} \mathrm{MJ}^{-1}\right)\end{array}$} \\
\hline & Boreal & Temperate \\
\hline TPM this study & $27(25-30)$ & $31(24-37)$ \\
\hline FEER TPM & 10 & 12 \\
\hline GFAS TPM & 25 & 8 \\
\hline GFED TPM & 25 & 10 \\
\hline QFED $\mathrm{PM}_{2.5}$ & 38 & 47 \\
\hline
\end{tabular}

tably, although differing in magnitude, all three top-down methods indicate slightly larger emission coefficients for temperate events. In contrast, more bottom-up approaches suggest 2.5 to 3 times larger emission coefficients for boreal forest. The TPM emission factors employed in GFAS and GFED inventories are identical for both forest types, 


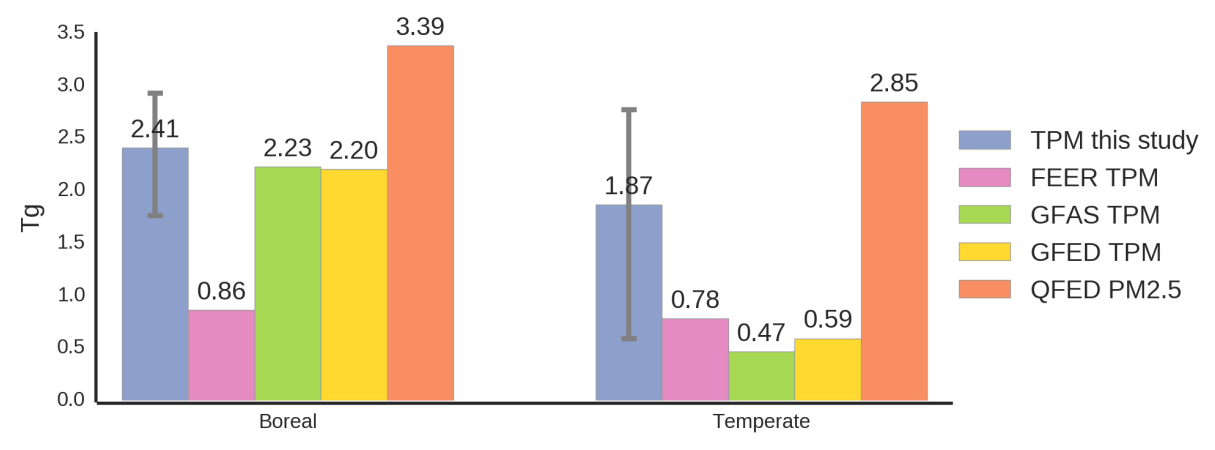

Figure 7. Total TPM emissions derived in this study and estimates for the same events and days of emission given by other methods. Error bars represent a $95 \%$ confidence interval, taking into account uncertainties in (i) AERONET retrievals, (ii) inferred water fraction, (iii) particle density, (iv) modelled $B_{\text {ext }}$ and (v) estimated error in attributed daily AOT.

but large differences exist in consumed biomass estimates. The GFAS inventory employs a 3-fold larger FRP to dry matter combustion rate conversion factor for boreal fires, attributable to high organic soil content in the biome. In contrast, emission coefficients for boreal and temperate forests derived in this study are statistically indistinguishable.

A number of factors may contribute towards the discrepancies between TPM estimates for this study and other methods. Relatively large estimates compared to near-source GFED, GFAS and FEER inventories may be influenced by unaccounted processes in ageing plumes. A several-fold growth in plume mass due to condensation and secondary particle production, however, seems implausible given that the reported magnitude of increase in particle mass driven by these processes is within 50\% (Reid and Hobbs, 1998). The difference may be partly due to large sizes of the events sampled in this study. Field measurements for large wildfires are scarce (Akagi et al., 2011; Urbanski, 2014), and such events are underrepresented in compiled EFs. The agreement between top-down and bottom-up methods is better for boreal fires than it is for temperate events. Fire event sizes are similar for both biomes, at least for the fires sampled. Therefore, it seems that fire size considerations alone fail to explain the varying degree of agreement between this study's TPM, and GFED and GFAS estimates when comparing boreal and temperate cases. Comparably low FEER estimates, apart from ageing effects, might be partly determined by sampled event size. Infrequent and large fires prevailing in North American forests make it difficult to reliably derive combustion coefficients from near the source imagery (Ichoku and Ellison, 2014).

Considering the above factors it seems that for the large fire events discussed, boreal emissions are underestimated by a factor close to 2 by the FEER inventory. Temperate TPM appears to be underestimated by factors of 2 to 4 by FEER, GFED and GFAS. QFED on the other hand, seems to overestimate particulate emissions by 40 to $50 \%$. The previously suggested GFAS TPM 2.2 enhancement factor seems to represent an average value for the region. It is not required for boreal fires, and is close to 4 for temperate plumes. While the underestimation by bottom-up GFED and GFAS may be driven by low-emission factors, the magnitude of the difference indicates that biomass-consumed estimates are the most likely source for discrepancies.

\section{Conclusions}

Refined particulate matter emission estimates are needed to improve future climate simulations and predict regional air quality at shorter timescales. Existing global estimates differ by a factor of 2-4. The method presented in this study enables the estimation of daily TPM emissions from large wildfires with identifiable plumes and sufficient satellite AOT observations. Daily estimates take into account particulate matter emitted throughout a full diurnal cycle including both daytime and night-time emissions. Importantly, repetitive estimates are obtained for the same period of emission during up to three consecutive days of plume evolution, allowing for an assessment of the AOT attribution error and systematic changes in smoke optical thickness over time.

Important insights are gained by partitioning plume AOT into daytime and night-time emissions. Night-time plume AOT seems to double when comparing observations of relatively young emissions of up to $18 \mathrm{~h}$ in age to AOT attributed to the same period of emission from the following day's imagery. Only small changes are observed after the subsequent $24 \mathrm{~h}$ of ageing. Daytime emitted AOT increases by approximately $30 \%$ for temperate fires, but does not change over time in boreal smoke. These changes have to be accounted for when reconciling emission estimates obtained near the source and from regionally dispersed aged plumes.

We utilized available coinciding AERONET observations to infer characteristic aerosol water content in discussed plumes and parameterize Mie calculations of smoke mass extinction efficiency. Coinciding AERONET retrievals indicate median water volume fractions of $0.15(0.1-0.31)$ and $0.47(0.29-0.67)$ for boreal and temperate plumes respec- 
tively. Calculated $B_{\text {ext }}$ of the dry particle fraction suggest median values of $5.7(5.1-6.5)$ and $6.5(5.5-9.2) \mathrm{m}^{2} \mathrm{~g}^{-1}$ for the two plume categories. The inferred water fractions indicate that hygroscopic growth accounts for the majority of the observed increase in plume optical thickness.

Daily total particulate matter emissions determined using simulated $B_{\text {ext }}$ indicate differences in agreement with other inventories for the two forest type fires. For boreal fires, which have higher median FRP values and burn predominantly during the daytime, TPM estimates agree closely with GFED and GFAS inventories, are higher by a factor of 2 compared to FEER and are lower by $30 \%$ than QFED PM 2.5 estimates. For temperate events, which are characterized by small changes in active fire pixel count throughout the diurnal cycle and generally lower median FRP values, the discrepancies are larger. Our TPM estimates are lower than QFED $\mathrm{PM}_{2.5}$ by $35 \%$, and higher by factors of $4,3.2$ and 2.4 compared to GFAS, GFED and FEER TPM estimates for the same emission events. The previously suggested scaling factor of 2.2 for GFAS particulate emissions is not required for boreal fires, but is too small for temperate events.

The large fire event bias and rapid ageing effects unaccounted for in this study could drive part of the difference, but are unlikely to explain all of it. Low FEER TPM for the discussed events could be attributed to these factors to a larger extent. The comparison of TPM obtained in this study to GFAS and GFED, however, suggest that TPM emission factors and consumed biomass estimates are underestimated for temperate fires within the bottom-up data sets.

Data availability. The results data set used for the interpretations is provided in the Supplement. HYSPLIT dispersion simulation data can be provided upon request to the corresponding author Tadas Nikonovas (tadas.nik@gmail.com). Note that the simulation results will be available for a limited time after the paper publication.

\section{The Supplement related to this article is available online at doi:10.5194/acp-17-6423-2017-supplement.}

Competing interests. The authors declare that they have no conflict of interest.

Acknowledgements. This research was supported by the Natural Environment Research Council (NERC) (Grant NE4/D501177/1). The authors gratefully acknowledge the AERONET team for their effort in establishing and maintaining the network, and for the data provision. They thank NOAA Air Resources Laboratory (ARL) for the provision of the HYSPLIT transport and dispersion model. They further thank people at the University of Maryland and NASA Fire Information for Resource Management System for creating and providing active fire location data set MCD14ML, NASA Atmosphere Archive and Distribution System for providing AOT products M*D04_L2, and teams behind GFED, GFAS, FEER and QFED emission inventories for producing and making the data sets available.

Edited by: A. Dastoor

Reviewed by: two anonymous referees

\section{References}

Akagi, S. K., Yokelson, R. J., Wiedinmyer, C., Alvarado, M. J., Reid, J. S., Karl, T., Crounse, J. D., and Wennberg, P. O.: Emission factors for open and domestic biomass burning for use in atmospheric models, Atmos. Chem. Phys., 11, 4039-4072, doi:10.5194/acp-11-4039-2011, 2011.

Andreae, M. O. and Merlet, P.: Emission of trace gases and aerosols from biomass burning, Global Biogeochem. Cy., 15, 955-966, doi:10.1029/2000GB001382, 2001.

Arola, A., Schuster, G., Myhre, G., Kazadzis, S., Dey, S., and Tripathi, S. N.: Inferring absorbing organic carbon content from AERONET data, Atmos. Chem. Phys., 11, 215-225, doi:10.5194/acp-11-215-2011, 2011.

Bohren, C. F. and Huffman, D. R.: Absorption and scattering of light by small particles, John Wiley \& Sons, New York, 1983.

Bond, T. C. and Bergstrom, R. W.: Light absorption by carbonaceous particles: an investigative review, Aerosol Sci. Tech., 40, 27-67, 2006.

Bond, T. C., Doherty, S. J., Fahey, D. W., Forster, P. M., Berntsen, T., DeAngelo, B. J., Flanner, M. G., Ghan, S., Kärcher, B., Koch, D., Kinne, S., Kondo, Y., Quinn, P. K., Sarofim, M. C., Schultz, M. G., Schulz, M., Venkataraman, C., Zhang, H., Zhang, S., Bellouin, N., Guttikunda, S. K., Hopke, P. K., Jacobson, M. Z., Kaiser, J. W., Klimont, Z., Lohmann, U., Schwarz, J. P., Shindell, D., Storelvmo, T., Warren, S. G., and Zender, C. S.: Bounding the role of black carbon in the climate system: a scientific assessment, J. Geophys. Res.-Atmos., 118, 5380-5552, doi:10.1002/jgrd.50171, 2013.

Brock, C. A., Cozic, J., Bahreini, R., Froyd, K. D., Middlebrook, A. M., McComiskey, A., Brioude, J., Cooper, O. R., Stohl, A., Aikin, K. C., de Gouw, J. A., Fahey, D. W., Ferrare, R. A., Gao, R.-S., Gore, W., Holloway, J. S., Hübler, G., Jefferson, A., Lack, D. A., Lance, S., Moore, R. H., Murphy, D. M., Nenes, A., Novelli, P. C., Nowak, J. B., Ogren, J. A., Peischl, J., Pierce, R. B., Pilewskie, P., Quinn, P. K., Ryerson, T. B., Schmidt, K. S., Schwarz, J. P., Sodemann, H., Spackman, J. R., Stark, H., Thomson, D. S., Thornberry, T., Veres, P., Watts, L. A., Warneke, C., and Wollny, A. G.: Characteristics, sources, and transport of aerosols measured in spring 2008 during the aerosol, radiation, and cloud processes affecting Arctic Climate (ARCPAC) Project, Atmos. Chem. Phys., 11, 2423-2453, doi:10.5194/acp-11-24232011, 2011.

Chand, D., Guyon, P., Artaxo, P., Schmid, O., Frank, G. P., Rizzo, L. V., Mayol-Bracero, O. L., Gatti, L. V., and Andreae, M. O.: Optical and physical properties of aerosols in the boundary layer and free troposphere over the Amazon Basin during the biomass burning season, Atmos. Chem. Phys., 6, 2911-2925, doi:10.5194/acp-6-2911-2006, 2006.

Colarco, P., Schoeberl, M., Doddridge, B., Marufu, L., Torres, O., and Welton, E.: Transport of smoke from Canadian forest fires to 
the surface near Washington, DC: injection height, entrainment, and optical properties, J. Geophys. Res.-Atmos., 109, D06203, doi:10.1029/2003JD004248, 2004.

Dahlkötter, F., Gysel, M., Sauer, D., Minikin, A., Baumann, R., Seifert, P., Ansmann, A., Fromm, M., Voigt, C., and Weinzierl, B.: The Pagami Creek smoke plume after long-range transport to the upper troposphere over Europe - aerosol properties and black carbon mixing state, Atmos. Chem. Phys., 14, 6111-6137, doi:10.5194/acp-14-6111-2014, 2014

Damoah, R., Spichtinger, N., Forster, C., James, P., Mattis, I., Wandinger, U., Beirle, S., Wagner, T., and Stohl, A.: Around the world in 17 days - hemispheric-scale transport of forest fire smoke from Russia in May 2003, Atmos. Chem. Phys., 4, 13111321, doi:10.5194/acp-4-1311-2004, 2004.

Darmenov, A. and da Silva, A.: The Quick Fire Emissions Dataset (QFED): Documentation of versions 2.1, 2.2 and 2.4. NASA/TM-2015-104606, 38, available at: http://gmao.gsfc.nasa. gov/pubs/docs/Darmenov796.pdf, last access: 1 December 2015.

Dick, W. D., Ziemann, P. J., and McMurry, P. H.: Multiangle lightscattering measurements of refractive index of submicron atmospheric particles, Aerosol Sci. Tech., 41, 549-569, 2007.

Draxler, R. and Rolph, G.: HYSPLIT (HYbrid Single-Particle Lagrangian Integrated Trajectory) model access via NOAA ARL READY website, available at: http://www.arl.noaa.gov/ready/ hysplit4.html (last access: 17 December 2014), NOAA Air Resources Laboratory, Silver Spring, 2003.

Dubovik, O. and King, M. D.: a flexible inversion algorithm for retrieval of aerosol optical properties from Sun and sky radiance measurements, J. Geophys. Res.-Atmos., 105, 20673-20696, 2000.

Dubovik, O., Smirnov, A., Holben, B., King, M., Kaufman, Y., Eck, T., and Slutsker, I.: Accuracy assessments of aerosol optical properties retrieved from Aerosol Robotic Network (AERONET) Sun and sky radiance measurements, J. Geophys. Res.-Atmos., 105, 9791-9806, 2000.

Dubovik, O., Holben, B., Eck, T. F., Smirnov, A., Kaufman, Y. J., King, M. D., Tanre, D., and Slutsker, I.: Variability of absorption and optical properties of key aerosol types observed in worldwide locations, J. Atmos. Sci., 59, 590-608, 2002.

Dubovik, O., Lapyonok, T., Kaufman, Y. J., Chin, M., Ginoux, P., Kahn, R. A., and Sinyuk, A.: Retrieving global aerosol sources from satellites using inverse modeling, Atmos. Chem. Phys., 8, 209-250, doi:10.5194/acp-8-209-2008, 2008.

French, N. H. F., Goovaerts, P., and Kasischke, E. S.: Uncertainty in estimating carbon emissions from boreal forest fires, J. Geophys. Res.-Atmos., 109, doi:10.1029/2003JD003635, 2004.

Giglio, L., Csiszar, I., and Justice, C. O.: Global distribution and seasonality of active fires as observed with the Terra and Aqua Moderate Resolution Imaging Spectroradiometer (MODIS) sensors, J. Geophys. Res., 111, doi:10.1029/2005JG000142, 2006.

Giglio, L., Randerson, J. T., and Van der Werf, G. R.: Analysis of daily, monthly, and annual burned area using the fourthgeneration global fire emissions database (GFED4), J. Geophys. Res., 118, 317-328, doi:10.1002/jgrg.20042, 2013.

Hobbs, P. V., Reid, J. S., Herring, J. A., Nance, J. D., and Weiss, R. E.: Particle and Trace-Gas Measurements in the Smoke from Prescribed Burns of Forest Products in the Pacific Northwest, in: Biomass Burning and Global Change, Vol. 1, edited by: Levine, J. S., MIT Press, New York, 1006, 697-715, 1996.
Hoffer, A., Gelencsér, A., Guyon, P., Kiss, G., Schmid, O., Frank, G. P., Artaxo, P., and Andreae, M. O.: Optical properties of humic-like substances (HULIS) in biomass-burning aerosols, Atmos. Chem. Phys., 6, 3563-3570, doi:10.5194/acp-6-3563-2006, 2006.

Holben, B., Eck, T., Slutsker, I., Tanre, D., Buis, J., Setzer, A., Vermote, E., Reagan, J., Kaufman, Y., Nakajima, T., Lavenu, F., Jankowiak, I., and Smirnov, A.: AERONET a federated instrument network and data archive for aerosol characterization, Remote Sens. Environ., 66, 1-16, 1998.

Hyer, E. J. and Reid, J. S.: Baseline uncertainties in biomass burning emission models resulting from spatial error in satellite active fire location data, J. Geophys. Res. Lett., 36, L05802, doi:10.1029/2008GL036767, 2009

Hyer, E. J., Reid, J. S., and Zhang, J.: An over-land aerosol optical depth data set for data assimilation by filtering, correction, and aggregation of MODIS Collection 5 optical depth retrievals, Atmos. Meas. Tech., 4, 379-408, doi:10.5194/amt-4-379-2011, 2011.

Ichoku, C. and Ellison, L.: Global top-down smoke-aerosol emissions estimation using satellite fire radiative power measurements, Atmos. Chem. Phys., 14, 6643-6667, doi:10.5194/acp14-6643-2014, 2014.

Ichoku, C. and Kaufman, Y. J.: a method to derive smoke emission rates from MODIS fire radiative energy measurements, IEEE T. Geosci. Remote, 43, 2636-2649, doi:10.1109/TGRS.2005.857328, 2005.

Janhäll, S., Andreae, M. O., and Pöschl, U.: Biomass burning aerosol emissions from vegetation fires: particle number and mass emission factors and size distributions, Atmos. Chem Phys., 10, 1427-1439, doi:10.5194/acp-10-1427-2010, 2010.

Johnston, F. H., Henderson, S. B., Chen, Y., Randerson, J. T., Marlier, M., DeFries, R. S., Kinney, P., Bowman, D. M., and Brauer, M.: Estimated global mortality attributable to smoke from landscape fires, Environ. Health Persp., 120, 695-701, 2012.

Kaiser, J. W., Heil, A., Andreae, M. O., Benedetti, A., Chubarova, N., Jones, L., Morcrette, J.-J., Razinger, M., Schultz, M. G., Suttie, M., and van der Werf, G. R.: Biomass burning emissions estimated with a global fire assimilation system based on observed fire radiative power, Biogeosciences, 9, 527-554, doi:10.5194/bg-9-527-2012, 2012.

Kasischke, E. S., Williams, D., and Barry, D.: Analysis of the patterns of large fires in the boreal forest region of Alaska, Int. J Wildland Fire, 11, 131-144, 2002.

Kaufman, Y. J. and Tanre, D.: Algorithm for remote sensing of tropospheric aerosol from MODIS, NASA MODIS Algorithm Theoretical Basis Document, Goddard Space Flight Center, Greenbelt, Md, 85 pp., 1998.

Kirchstetter, T. W., Novakov, T., and Hobbs, P. V.: Evidence that the spectral dependence of light absorption by aerosols is affected by organic carbon, J. Geophys. Res.-Atmos., 109, D21208, doi:10.1029/2004JD004999, 2004.

Kotchenmther, R. A. and Hobbs, P. V.: Humidification factors of aerosols from biomass burning, J. Geophys. Res.-Atmos., 104, 2239-2251, 1998.

Kreidenweis, S. M., Remer, L. A., Bruintjes, R., and Dubovik, O.: Smoke aerosol from biomass burning in Mexico: Hygroscopic 
smoke optical model, J. Geophys. Res.-Atmos., 106, 4831-4844, doi:10.1029/2000JD900488, 2001.

Langmann, B., Duncan, B., Textor, C., Trentmann, J., and van der Werf, G. R.: Vegetation fire emissions and their impact on air pollution and climate, Atmos. Environ., 43, 107-116, 2009.

Levy, R. C., Remer, L. A., Tanre, D., Mattoo, S., and Kaufman, Y. J.: Algorithm for Remote Sensing of Tropospheric Aerosol over Dark Targets from MODIS: Collections 005 and 051: Revision 2, February 2009, available at: http://modis-atmos.gsfc.nasa.gov/ _docs/ATBD_MOD04_C005_rev2.pdf (last access: 24 February 2015), 2009.

Levy, R. C., Remer, L. A., Kleidman, R. G., Mattoo, S., Ichoku, C., Kahn, R., and Eck, T. F.: Global evaluation of the Collection 5 MODIS dark-target aerosol products over land, Atmos. Chem. Phys., 10, 10399-10420, doi:10.5194/acp-10-10399-2010, 2010.

Livingston, J. M., Redemann, J., Shinozuka, Y., Johnson, R., Russell, P. B., Zhang, Q., Mattoo, S., Remer, L., Levy, R., Munchak, L., and Ramachandran, S.: Comparison of MODIS $3 \mathrm{~km}$ and $10 \mathrm{~km}$ resolution aerosol optical depth retrievals over land with airborne sunphotometer measurements during ARCTAS summer 2008, Atmos. Chem. Phys., 14, 2015-2038, doi:10.5194/acp-142015-2014, 2014.

Liu, Y., Stanturf, J., and Scott, G.: Trends in global wildfire potential in a changing climate, Forest Ecol. Manag., 259, 685-697,2013.

Magi, B. I. and Hobbs, P. V.: Effects of humidity on aerosols in southern Africa during the biomass burning season, J. Geophys. Res.-Atmos., 108, 2156-2202, 2003

Nikonovas, T., North, P. R. J., and Doerr, S. H.: Smoke aerosol properties and ageing effects for northern temperate and boreal regions derived from AERONET source and age attribution, Atmos. Chem. Phys., 15, 7929-7943, doi:10.5194/acp-15-79292015, 2015.

O’Neill, N. T., Eck, T. F., Holben, B. N., Smirnov, A., Royer, A., and Li, Z.: Optical properties of boreal forest fire smoke derived from Sun photometry, J. Geophys. Res.-Atmos., 107, AAC 6-1AAC 6-19, doi:10.1029/2001JD000877, 2002.

Peterson, D., Hyer, E., and Wang, J.: Quantifying the potential for high-altitude smoke injection in the North American boreal forest using the standard MODIS fire products and subpixelbased methods, J. Geophys. Res.-Atmos., 119, 3401-3419, doi:10.1002/2013JD021067, 2014.

Randerson, J. T., Chen, Y., Van der Werf, G. R., Rogers, B. M., and Morton, D. C.: Global burned area and biomass burning emissions from small fires, J. Geophys. Res., 117, G04012, doi:10.1029/2012JG002128, 2012.

Reid, J. S., Koppmann, R., Eck, T. F., and Eleuterio, D. P.: A review of biomass burning emissions part II: intensive physical properties of biomass burning particles, Atmos. Chem. Phys., 5, 799825, doi:10.5194/acp-5-799-2005, 2005a.

Reid, J. S., Eck, T. F., Christopher, S. A., Koppmann, R., Dubovik, O., Eleuterio, D. P., Holben, B. N., Reid, E. A., and Zhang, J.: A review of biomass burning emissions part III: intensive optical properties of biomass burning particles, Atmos. Chem. Phys., 5, 827-849, doi:10.5194/acp-5-827-2005, 2005b.

Reid, J. S. and Hobbs, P. V.: Physical and optical properties of young smoke from individual biomass fires in Brazil, J. Geophys. Res.Atmos., 103, 32013-32030, 1998.
Rudich, Y., Donahue, N. M., and Mentel, T. F.: Aging of organic aerosol: Bridging the gap between laboratory and field studies, Annu. Rev. Phys. Chem., 58, 321-352, 2007.

Saide, P. E., Peterson, D. A., da Silva, A., Anderson, B., Ziemba, L. D., Diskin, G., Sachse, G., Hair, J., Butler, C., Fenn, M., Jimenez, J. L., Campuzano-Jost, P., Perring, A. E., Schwarz, J. P., Markovic, M. Z., Russell, P., Redemann, J., Shinozuka, Y., Streets, D. G., Yan, F., Dibb, J., Yokelson, R., Toon, O. B., Hyer, E., and Carmichael, G. R.: Revealing important nocturnal and day-to-day variations in fire smoke emissions through a multiplatform inversion, Geophys. Res. Lett., 42, 3609-3618, doi:10.1002/2015GL063737, 2015.

Schuster, G. L., Dubovik, O., Holben, B. N., and Clothiaux, E. E.: Inferring black carbon content and specific absorption from Aerosol Robotic Network (AERONET) aerosol retrievals, J Geoph. Res.-Atmos., 110, doi:10.1029/2004JD004548, 2005.

Schuster, G. L., Lin, B., and Dubovik, O.: Remote sensing of aerosol water uptake, Geophys. Res. Lett., 36, L03814, doi:10.1029/2008GL036576, 2009.

Schuster, G. L., Dubovik, O., and Arola, A.: Remote sensing of soot carbon - Part 1: Distinguishing different absorbing aerosol species, Atmos. Chem. Phys., 16, 1565-1585, doi:10.5194/acp16-1565-2016, 2016.

Stocks, B. J., Mason, J. A., Todd, J. B., Bosch, E. M., Wotton, B. M., Amiro, B. D., Flannigan, M. D., Hirsch, K. G., Logan, K. A., Martell, D. L., and Skinner, W. R.: Large forest fires in Canada, 1959-1997, J. Geophys. Res.-Atmos., 107, 8149, doi:10.1029/2001JD000484, 2002.

Strauss, D., Bednar, L., and Mees, R.: Do one percent of the forest fires cause ninety-nine percent of the damage?, Forest Sci., 35, 319-328, 1989.

Swietlicki, E., Hansson, H.-C., Hämeri, K., Svenningsson, B., Massling, A., Mcfiggans, G., Mcmurry, P. H., Petäjä, T., Tunved, P., Gysel, M., Topping, D., Weingartner, E., Baltensperger, U., Rissler, J., Wiedensohler, A., and Kulmala, M.: Hygroscopic properties of submicrometer atmospheric aerosol particles measured with H-TDMA instruments in various environments - a review, Tellus B, 60, 432-469, doi:10.1111/j.16000889.2008.00350.x, 2008.

Toon, O. B., Pollack, J. B., and Khare, B. N.: The optical constants of several atmospheric aerosol species: Ammonium sulfate, aluminum oxide, and sodium chloride, J. Geophys. Res., 81, 57335748, doi:10.1029/JC081i033p05733, 1976.

Turetsky, M., R., Benscoter, B., Page, S., Rein, G., Van der Werf, G. R., and Watts, A.: Global vulnerability of peatlands to fire and carbon loss, Nat. Geosci., 8, 11-14, 2015.

Turpin, B. J. and Lim, H.: Species Contributions to $\mathrm{PM}_{2.5}$ Mass Concentrations: Revisiting Common Assumptions for Estimating Organic Mass, Aerosol Sci. Tech., 35, 602-610, doi:10.1080/02786820119445, 2001.

Urbanski, S.: Wildland fire emissions, carbon, and climate: Emission factors, Forest Ecol. Manag., 317, 51-60, doi:10.1016/j.foreco.2013.05.045, 2014.

Val Martin, M., Logan, J. A., Kahn, R. A., Leung, F.-Y., Nelson, D. L., and Diner, D. J.: Smoke injection heights from fires in North America: analysis of 5 years of satellite observations, Atmos. Chem. Phys., 10, 1491-1510, doi:10.5194/acp-10-14912010, 2010. 
van der Werf, G. R., Randerson, J. T., Giglio, L., Collatz, G. J., Mu, M., Kasibhatla, P. S., Morton, D. C., DeFries, R. S., Jin, Y., and van Leeuwen, T. T.: Global fire emissions and the contribution of deforestation, savanna, forest, agricultural, and peat fires (19972009), Atmos. Chem. Phys., 10, 11707-11735, doi:10.5194/acp10-11707-2010, 2010.

van Leeuwen, T. T. and van der Werf, G. R.: Spatial and temporal variability in the ratio of trace gases emitted from biomass burning, Atmos. Chem. Phys., 11, 3611-3629, doi:10.5194/acp11-3611-2011, 2011.

van Leeuwen, T. T., van der Werf, G. R., Hoffmann, A. A., Detmers, R. G., Rücker, G., French, N. H. F., Archibald, S., Carvalho Jr., J. A., Cook, G. D., de Groot, W. J., Hély, C., Kasischke, E. S., Kloster, S., McCarty, J. L., Pettinari, M. L., Savadogo, P., Alvarado, E. C., Boschetti, L., Manuri, S., Meyer, C. P., Siegert, F., Trollope, L. A., and Trollope, W. S. W.: Biomass burning fuel consumption rates: a field measurement database, Biogeosciences, 11, 7305-7329, doi:10.5194/bg-11-7305-2014, 2014.
Wooster, M. J., Zhukov, B., and Oertel, D.: Fire radiative energy for quantitative study of biomass burning: derivation from the $\{B I R D\}$ experimental satellite and comparison to \{MODIS \} fire products, Remote Sens. Environ., 86, 83-107, doi:10.1016/S0034-4257(03)00070-1, 2003.

Wooster, M. J., Roberts, G., Perry, G. L. W., and Kaufman, Y. J.: Retrieval of biomass combustion rates and totals from fire radiative power observations: FRP derivation and calibration relationships between biomass consumption and fire radiative energy release, J. Geophys. Res.-Atmos., 110, D24311, doi:10.1029/2005JD006318, 2005. 